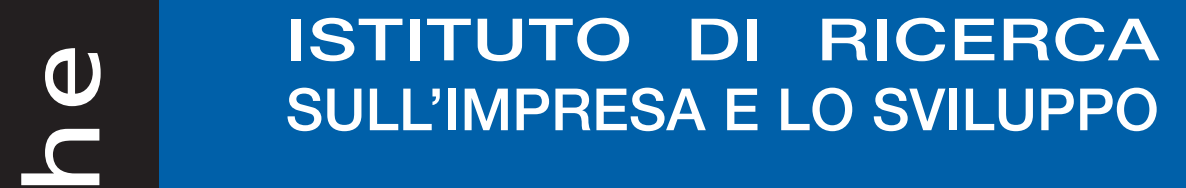
ISSN (on line): 2036-8216

\begin{tabular}{l}
$U$ \\
$U$ \\
$U$ \\
$U$ \\
\hline
\end{tabular}

$\frac{0}{\frac{0}{0}}$

(1)

$\frac{1}{0}$

N

Z

O

므

흐

믐

n

c

0

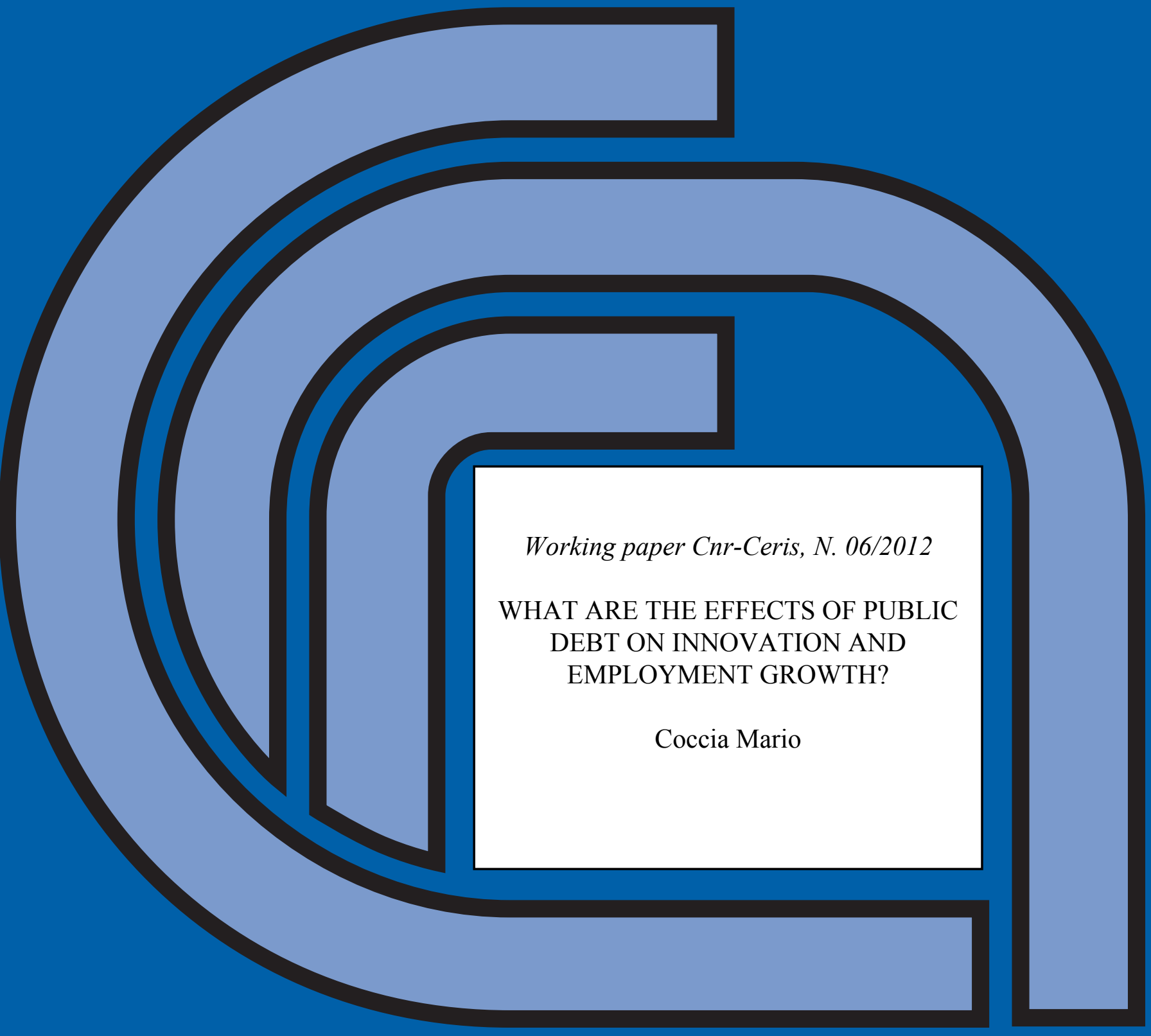

U

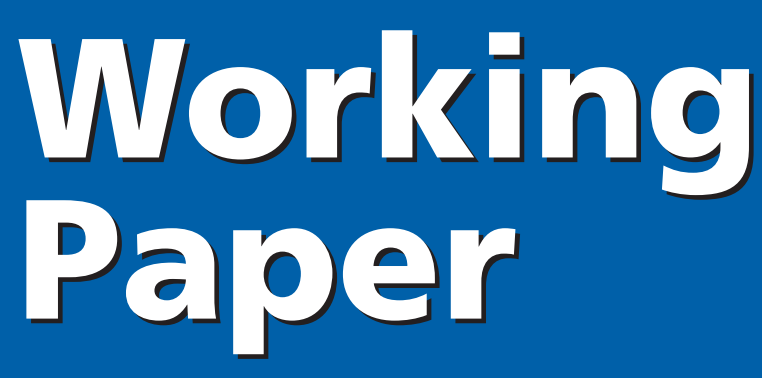




\section{(1) Consiglio Nazionale delle Ricerche \\ 드르 ISTITUTO DI RICERCA SULL'IMPRESA E LO SVILUPPO \\ WORKING PAPER CNR - CERIS \\ RIVISTA SOGGETTA A REFERAGGIO INTERNO ED ESTERNO}

ANNO 14, $\mathrm{N}^{\circ} 6-2012$

Autorizzazione del Tribunale di Torino

N. 2681 del 28 marzo 1977

ISSN (print): 1591-0709

ISSN (on line): 2036-8216

DIRETTORE RESPONSABILE

Secondo Rolfo

DIREZIONE E REDAZIONE

Cnr-Ceris

Via Real Collegio, 30

10024 Moncalieri (Torino), Italy

Tel. +390116824.911

Fax +390116824.966

segreteria@ceris.cnr.it http://www.ceris.cnr.it

SEDE DI ROMA

Via dei Taurini, 19

00185 Roma, Italy

Tel. +3906 49937810

Fax +39 0649937884

SEDE DI MILANO

Via Bassini, 15

20121 Milano, Italy

tel. +3902 23699501

Fax +39 0223699530

SEGRETERIA DI REDAZIONE

Enrico Viarisio

e.viarisio@ ceris.cnr.it

DISTRIBUZIONE

On line:

http://www.ceris.chr.it/index.php?option=com_content\&task=section \&id=4\&Itemid=64

FOTOCOMPOSIZIONE E IMPAGINAZIONE

In proprio

Finito di stampare nel mese di Aprile 2012

\section{COMITATO SCIENTIFICO}

Secondo Rolfo

Giulio Calabrese

Elena Ragazzi

Maurizio Rocchi

Giampaolo Vitali

Roberto Zoboli

\section{Copyright $\odot 2012$ by Cnr-Ceris}

All rights reserved. Parts of this paper may be reproduced with the permission of the author(s) and quoting the source. Tutti i diritti riservati. Parti di quest'articolo possono essere riprodotte previa autorizzazione citando la fonte. 


\title{
What are the effects of public debt on innovation and employment growth?
}

\author{
Coccia Mario \\ CNR - National Research Council of Italy \\ \& GEORGIA INSTITUTE OF TECHNOLOGY
}

Current Address:

School of Public Policy at Georgia Institute of Technology 685 Cherry Street, N.W. - Suite 217

Atlanta, Georgia 30332-0345
Permanent address:

CERIS- CNR via Real Collegio, n. 30 10024 Moncalieri (Torino) - Italy

Tel.: +39/0116824925

Fax : +39/0116824966

e-mail m.coccia@ceris.cnr.it

\begin{abstract}
The study here analyzes, across European countries, the relationship between labour and drivers of technological innovation, also considering the interaction of these variables with the structural indicator of the public debt. The main findings are: the fruitful effect of total public expenditure on education as a percentage of GDP and R\&D intensity on employment rate, whereas an increase of general government consolidated gross debt has a negative effect for employment rate as well as for technology proxies. Empirical evidence provides some elements to discuss main economic policy implications from relationships between observed facts.
\end{abstract}

Keywords: Employment Growth, Labour, R\&D Intensity, Technological Innovation, Education, Public Debt.

JEL Codes: J01; J08; I20; H63; O30; O33

I thank Vittorio Valli (University of Torino), John Walsh (School of Public Policy, Georgia Institute of Technology, Atlanta) and Levent Kutlu (School of Economics, Georgia Institute of Technology, Atlanta) for main suggestions to a preliminary draft of this paper. I also thank Ruth Uwaifo Oyelere (Georgia Institute of Technology and IZA Fellow, Bonn Germany), participants at the 2012 Spring Seminar Series - School of Economics (Georgia Institute of Technology) and 2012 Triple Helix International Conference Committee for fruitful comments and suggestions. Special thanks to Ceris-CNR and Georgia Institute of Technology staff for research support. In addition, I gratefully acknowledge financial support from the CNR National Research Council of Italy for my visiting at Yale University and Georgia Institute of Technology where this research has been originated and developed. Diego Margon and Silvana Zelli provided excellent research assistance. The usual disclaimer holds, however. 


\section{CONTENTS}

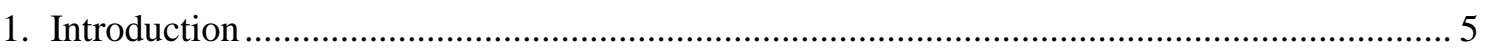

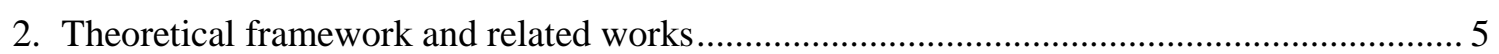

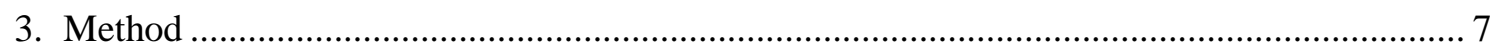

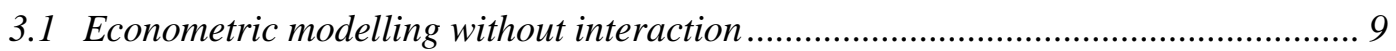

3.2 Econometric modelling with interaction ……...................................................... 9

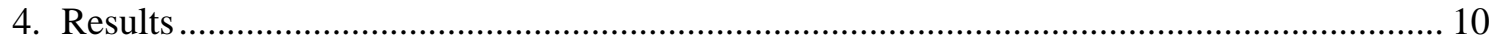

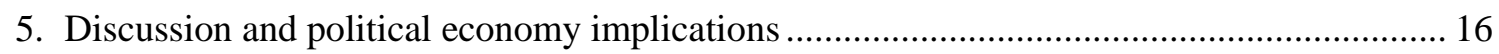

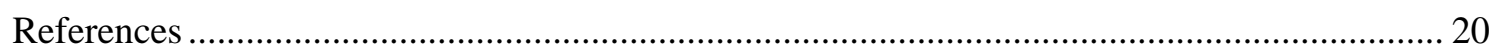

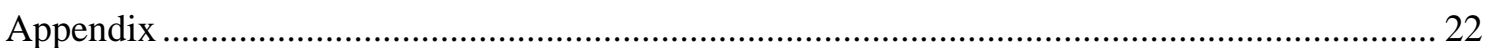




\section{INTRODUCTION}

The aim of this paper is to answer to the following question:

- How do R\&D intensity and spending on human resources affect the employment rate of countries, also considering the critical macroeconomic indicator of the public debt?

In order to understand, within current economic systems, the impact of driving technological forces on employment growth, it is important to analyze how technological determinants and employment variables interact with public debt. In fact, the macroeconomic variable of the public debt of countries affects, within the framework of the political economy of growth, the government expenditure on $R \& D$ and on human resources that play a vital role to spur employment growth.

Economic literature is abundant of studies that analyze the role of technology, employment and economic growth ( $c f$. Addison and Teixeira, 2001; Corley et al., 2002; Michie et al., 2002; Antonucci and Pianta, 2002; Mastrostefano and Pianta, 2009; Bogliacino and Pianta, 2010). In particular, as technological progress is a main driver of economic growth, and technical knowledge is the engine of technological innovations, modern economic growth theory is focused on endogenous growth approach that considers the accumulation of physical and human capital (Lucas, 1988; Caballé and Santos, 1993) and R\&D-based models (Romer, 1990; Grossman and Helpman, 1991; Aghion and Howitt, 1992). The critical role of R\&D and spending on human resources for employment growth is consistent within the recent empirical literature which emphasizes the fruitful effect of some innovations for employment of firms, industries and countries (Pini, 1995; Goel et al., 2008; Grossman, 2007). Several works have provided many valuable insights into the theory of technological innovation, although, how public debt of countries can affect national spending on R\&D and human resources for supporting employment growth has not been accurately explored by economists of technical change. The study here investigates this main economic issue in order to contribute to the debate on the relationship between innovation and employment, also considering the interaction with public debt. In fact, sovereign debt has a main role for economic stability and steady-state pattern of economic growth of countries; in addition, the high/low level of public debt can affect available economic and financial resources to design apt political economy of growth (Amaral and Jacobson, 2011). For this reason, modern economic literature considers, more and more, the role of public debt and balanced-budget rules for spurring long-run patterns of employment and economic growth (SchmittGrohé and Uribe, 1997, Stockman, 2001; Sargent, 2012). The findings of this research can provide main results to understand the critical interaction of key variables for economic growth and to support best-practices on innovation and education in order to minimize the unemployment over time. The paper is laid out as follows: section 2 describes the theoretical framework of the study, section 3 presents data source and method of research, section 4 shows the main results and section 5 discusses the empirical evidence and concludes.

\section{THEORETICAL FRAMEWORK AND RELATED WORKS}

Europe has been experiencing high level of unemployment since 1990s (Michie et al. 2002, p. 253ff; Addison and Teixeira, 2001, p. 191, Sapir et al., 2004) ${ }^{1}$. The European unemployment seems to increase after the fiscal rules of the Maastricht treatise, the background of Euro currency, since several member-countries have been designing economic policies that focus on austerity packages and balanced-budget rules to support their stability, creating damping factors for economic growth into the Eurozone. The relationship between innovation and employment of countries has been widely investigated by economic models coupled with empirical evidence, and in the economic literature is accepted that technical knowledge and investments in $R \& D$ play a key role for employment growth (e.g. Bogliacino and Pianta, 2010). A first problem to deal with is the difficulty of measuring the innovation with accuracy; scholars mainly use $R \& D$ expenditure, patents, spending on human resources, etc., to analyze the directions of technological change and assess the impact on economic variables such as employment, productivity, GDP per capita,

1 Cf. the special issue of International review of applied economics, vol.16, n. 2, 2003. 
and so on. According to Acemoglu (2002, p. 7): "technical change favors more skilled workers, replaces tasks previously performed by the unskilled, and exacerbates inequality". In fact, technological choices by countries can affect wage inequality because of different incentives created by labor-market institutions (Acemoglu, 2002, p. 14). In addition, "skill-bias technological change" can generate effects of friction on TFP ${ }^{2}$ due to imbalance composition of $R \& D$ (Acemoglu, 2002, p. 12). Addison and Teixeira (2001, p. 191) analyze the role of the technology as a factor that has been rising unskilled worker unemployment and consider as long-run solution the improvements of educational system. In particular, the increase of educated workers in employment is a main determinant of "relative demand shifts in their favor" (Addison and Teixeira, 2001, p. 192). In fact, "technological proxies such as R\&D expenditures ... have been found to have a positive and statistically significant effects on the employment ... of nonproduction/skilled workers in country and crosscountry studies alike" (Addison and Teixeira, 2001, p. 214). In addition, it is also important to note that the technological pathways of industries and countries can affect the structure of employment and the effects of innovation on employment change. Mostrostefano and Pianta (2009, p. 729ff.), analyzing the relationship innovation-employment, show that product innovations, driven by $\mathrm{R} \& \mathrm{D}$, foster employment at firm level when is associated to a sustainable demand, while process innovations tend to reduce employment and productivity growth because of the substitution of labour with capital (cf. also Bogliacino and Pianta, 2010, p. 805). Negative effects of innovation process on employment have also been stressed by Pini (1995, pp.208209).

As far as industries are concerned, a main role is played by structural change of the economic system, and low employment growth and/or reduction is associated to low demand, low product innovations and introduction of "labour saving process innovation" (Mastrostefano and Pianta, 2009, p. 729). Mastrostefano and Pianta

2 Total-Factor Productivity (TFP) is a variable which accounts for effects in total output not caused by traditionally measured inputs. It can be a measure of long-term technological change by economies.
(2009, p. 737) show that high-tech industries are mainly dominated by product innovations with fruitful effects for employment growth, whereas industries with low technology have a prevalence of process innovations and a negative impact on employment. Corley et al. (2002, p. 265ff) claim that to spur employment in high-tech sector it is necessary an investment in R\&D, physical and human capital. These main results support the analysis by Antonucci and Pianta (2002, p. 306) that argue how the high level of European unemployment in comparison with US economy is due to manufacturing sector based on industries with low product innovations and more process innovations. In fact, the specificity of European industrial structure, affected by economic turbulence and low demand growth, can have continuous negative effects for patterns of employment and economic growth. Pini (1995, p. 208) finds that within European countries the innovation process (as input) has a main effects on employment, whereas as output has not a "compensation effects through growth in exports".

Funke and Strulik (2000) present a model with different theories of growth (neoclassical, endogenous growth by physical capital and human capital accumulation and R\&D-based growth model). They show the main role of education and training because "perpetual growth of ideas .. . requires the accumulation of knowledge" (Funke and Strulik, 2000, p. 512) as well as the knowledge positive spillover plays can support long-run technological progress. Instead, Bogliacino and Pianta (2010, p. 805) investigate how technological change affects employment across industries, analyzing a revised Pavitt taxonomy. They describe the best performer industries: a) science based industries, based on product innovations and low significant effect of process innovation, and $b$ ) specialized supplier industries where the employment is affected by low positive effect of product innovation and a high negative impact of new labour saving processes. In addition, their empirical evidence shows a declining employment in scale and information intensive sectors and supplier dominated industries due to innovation process and a "strategy of cost competitiveness". Hence, the main role of innovations for employment growth is widely displayed within the economic literature, which shows as different innovations have different 
impacts on industries, economic growth and labour force (cf. David et al., 2000). Other scholars, such as Goel et al. (2008, p. 247) claim that $R \& D$ spending has higher social returns with fruitful effects on employment and show the higher association between economic growth and federal $R \& D$, rather than non-federal $R \& D$. Instead, Grossman (2007, p. 893) suggests that public R\&D spending should be targeted to the supply of education and skills to promote R\&Dbased growth. In particular, this strategy plays a critical role for innovations and performances of firms (productivity growth) and does not affect income distribution (Grossman, 2007, p. 905). "[T]he optimal structure of public education spending . . . depends on the relative effectiveness of the education sector across fields and its interaction with technological characteristics of firms' $R \& D$ and production activity" (Grossman, 2007, p. 905).

These and other studies confirm that the relationship between employment and innovation has attracted much scholarly attention and it deserves new investigations, in period of economic turbulence that increases unemployment level, also considering other critical structural indicators, such as the public debt that can affect a comprehensive political economy to support employment growth.

In fact, Ogawa (2007, p. 404), focusing on Japanese manufacturing sector, analyses how outstanding debts affect R\&D investment and technological progress of firms. Results show as the ratio debt to total asset has a significant and negative impact on $R \& D$ investment and opportunity of growth. As the impact of technological indicators changes according to firms and industries, the study here focuses on national data of European countries, investigating how a main structural indicator, the public debt, interacts with $R \& D$ expenditures and spending on human resources and, as consequence, employment growth. In fact, the role of the public debt is important because it affects the capacity of spending in R\&D and education that are main drivers of employment growth. This analysis can provide main results that should be assessed in association with austerity packages and balanced-budget rules of countries in order to avoid aggregate instability and chaotic equilibria of economic systems with negative repercussions on employment and pattern of economic growth (cf. Schmitt-Grohé and Uribe, 1997, Stockman, 2010).

\section{METHOD}

The purpose of this paper is to investigate, at aggregate level across European countries, the relationship between employment and innovation, also considering the interaction of the public debt. The study is based on 27 European countries that represent a homogenous sample over the 1995-2009 period.

Models consider the following assumption and hypotheses.

Assumption: A balanced national system of innovation (in broad terms) ${ }^{3}$ and economic system (with low public debt) support the national employment growth.

Two critical hypotheses (Hp) are:

\section{Hp 1: Spending in education and research has a fruitful effect for employment of countries.}

\section{Hp 2: Public debt reduction spurs the level of employment of the economic system.}

Remark: Hp 2 is supported by arguments that lower public debt, increase the stability of the economic system that supports the banking and funding system of countries, and as consequence, patterns of employment and economic growth.

The empirical methodology has the aim to see whether statistical evidence supports these hypotheses, in order to understand the interlinked economic and technological forces that support employment growth of countries. In particular, the research strategy analyzes the relationship between employment, innovation and their interaction with public debt. As far as employment and public debt are concerned, there are univocal measurements (see table 1), whereas the accurate measurement of the innovation

\footnotetext{
3 The national system of innovation (NSI) refers to the complex network of agents, policies, and institutions supporting the process of technical advance in an economy (Lundvall, 1992). The narrow definition of NSI would include the subsystem research sector represented by universities, research laboratories, while the broad NSI includes many subsystems such as finance, firms, government, and so on. The efficiency of this broad NSI supports economic growth patterns.
} 
variable is a difficult task. In economics, to analyze the technological innovations and assess their impact on economic variables, the following metrics are used: $R \& D$ expenditures, $R \& D$ intensity (R\&D/GDP), patents, total public expenditure on education, etc. This research applies the following main technological proxies: $\mathrm{R} \& \mathrm{D}$ expenditures as percentage of GDP and public expenditure on education ( $c f$. Addison and Teixeira, 2001). Strulik (2005, p. 131), following Jones within the semi-endogenous growth model, considers the economic growth associated to the growth rate of effort in $\mathrm{R} \& \mathrm{D}$, supporting the interpretation that people became skillful scientists by education and that few skilled scientists produce more knowledge than nonskilled ones. The technological proxies of technological innovation, employment and public debt variables are described in table 1 .

Original data have been subjected to a process of horizontal and vertical cleaning, eliminating outliers. The normal distribution of variables is checked by Curtosi and Skewness coefficients, as well as by the normal Q-Q plot to ensure the correct estimates of parameters.

First of all, data have been analyzed by bivariate correlation and partial correlation controlling the public debt. After that, the econometric modeling has been applied considering the following two model setting.

Table 1 - Variables

\begin{tabular}{|c|c|}
\hline Variables /Period & Short Description \\
\hline $\begin{array}{l}\text { Employment rate } \\
2000-2009 \% \\
\text { EMP } 2000-2009\end{array}$ & $\begin{array}{l}\text { The employment rate } \% \text { is calculated by dividing the number of persons } \\
\text { aged } 15 \text { to } 64 \text { in employment by the total population of the same age } \\
\text { group. The indicator is based on the EU Labour Force Survey. The } \\
\text { survey covers the entire population living in private households and } \\
\text { excludes those in collective households such as boarding houses, halls of } \\
\text { residence and hospitals. Employed population consists of those persons } \\
\text { who during the reference week did any work for pay or profit for at least } \\
\text { one hour, or were not working but had jobs from which they were } \\
\text { temporarily absent. }\end{array}$ \\
\hline $\begin{array}{l}\text { Gross domestic expenditure on } \\
\text { R\&D (GERD) } \\
\text { Percentage of GDP 1995-2004 } \\
\text { GERD 1995-2004 }\end{array}$ & $\begin{array}{l}\text { The indicator provided is GERD (Gross domestic expenditure on R\&D) } \\
\text { as a percentage of GDP. "Research and experimental development } \\
\text { (R\&D) comprise creative work undertaken on a systematic basis in order } \\
\text { to increase the stock of knowledge, including knowledge of man, culture } \\
\text { and society and the use of this stock of knowledge to devise new } \\
\text { applications" (Frascati Manual, } 2002 \text { edition, } \S 63 \text { ). R\&D is an activity } \\
\text { where there are significant transfers of resources between units, } \\
\text { organizations and sectors and it is important to trace the flow of R\&D } \\
\text { funds. }\end{array}$ \\
\hline $\begin{array}{c}\text { Spending on Human Resources } \\
\text { Total public expenditure on } \\
\text { education as a percentage } \\
\text { of GDP1995-2004 } \\
\text { SPENDING HR 1995-2004 }\end{array}$ & $\begin{array}{l}\text { Generally the public sector funds the education either by bearing directly } \\
\text { the current and capital expenses of educational institutions (direct } \\
\text { expenditure for educational institutions) or by supporting students and } \\
\text { their families with scholarships and public loans as well as by } \\
\text { transferring public subsidies for educational activities to private firms or } \\
\text { non-profit organizations (transfers to private households and firms). Both } \\
\text { types of transaction together are reported as total public expenditure on } \\
\text { education. }\end{array}$ \\
\hline $\begin{array}{c}\text { General government consolidated } \\
\text { gross debt as a percentage } \\
\text { of GDP1997-2006 } \\
\text { DEBT1997-2006 }\end{array}$ & $\begin{array}{l}\text { EU definition: the general government sector comprises the subsectors of } \\
\text { central government, state government, local government and social } \\
\text { security funds. GDP used as a denominator is the gross domestic product } \\
\text { at current market prices. Debt is valued at nominal (face) value, and } \\
\text { foreign currency debt is converted into national currency using end-year } \\
\text { market exchange rates (though special rules apply to contracts). The } \\
\text { national data for the general government sector are consolidated between } \\
\text { the sub-sectors. Basic data are expressed in national currency, converted } \\
\text { into euro using end-year exchange rates for the euro provided by the } \\
\text { European Central Bank. }\end{array}$ \\
\hline
\end{tabular}

Source: Eurostat (2012) 


\subsection{Econometric modelling without interaction}

The functional relationship is:

Employment $_{i, t}=f(R \& D$ intensity, Expenditure in Education, General government consolidated gross debt $_{i, t-n}$

The specification is based on a multiple regression model with three explanatory variables:

$$
\begin{aligned}
& E_{i,(2000-2009)}=\lambda_{0}+\lambda_{1} \text { Spending } H R_{i,(1995-2004)}+ \\
& +\lambda_{2} G_{i,(1995-2004)}+\lambda_{3} D D_{i,(1997-2006)}+u_{i, t} \\
& E M P_{i,(t-\Delta t)}=\lambda_{0}+\lambda_{1}{\text { Spending } H R_{i,(t-\Delta t)}+}_{+}+\lambda_{2} \text { GERD }_{i,(t-\Delta t)}+\lambda_{3} D E B T_{i,(t-\Delta t)}+u_{i, t-\Delta t}
\end{aligned}
$$

where:

$i$ subscript indicates the country $t$ the time $u_{i, t}=$ error term

This is an apt model to analyze the effects of two critical technological variables and one main economic structural indicator on employment growth. This equation is estimated by ordinary last squares method, stepwise method (Criteria: Probability-of- $F$-to-enter $\leq 0.05$, Probability-of$F$-to-remove $\geq 0.10$ ), applying the statistics software SPSS (Statistical Package for the Social Sciences).

\subsection{Econometric modelling with interaction}

The second modeling considers the interaction terms, in particular:

$$
\begin{aligned}
& \text { INTER } 1=\text { DEBT } \times \text { SPENDING IN HR } \\
& I N T E R 2=D E B T \times G E R D \\
& I N T E R 3=G E R D \times \text { SPENDING IN HR }
\end{aligned}
$$

The specification of the econometric modeling is:

$$
\begin{aligned}
& \operatorname{EMP}_{i,(2000-2009)}=\lambda_{0}+\lambda_{1} \text { Spending } \mathrm{HR}_{i,(1995-2004)}+ \\
& \lambda_{2} \text { GERD }_{i,(1995-2004)}+\lambda_{3} D E B T_{i,(1997-2006)}+ \\
& +\lambda_{4} I N T E R 1+\lambda_{5} \text { INTER } 2+\lambda_{6} \text { INTER } 3+\varepsilon_{i, t}
\end{aligned}
$$

where:

$i$ subscript indicates the country $t$ the time.

$\varepsilon_{i, t}=$ error term.

$$
\begin{aligned}
& \text { EMP }_{i,(t-\Delta t)}=\lambda_{0}+\lambda_{1} \text { Spending } \operatorname{HR}_{i,(t-\Delta t)}+ \\
& +\lambda_{2} G D_{i,(t-\Delta t)}+\lambda_{3} \text { DEBT } \\
& +\lambda_{i,(t-\Delta t)}+ \\
& +\lambda_{4} \text { INTER } 1+\lambda_{5} \text { INTER } 2+\lambda_{6} \text { INTER } 3+\varepsilon_{i, t-\Delta t}
\end{aligned}
$$

This equation of multiple regression is also estimated by ordinary last squares method, stepwise method (Criteria: Probability-of- $F$-toenter $\leq 0.050, \quad$ Probability-of- $F$-to-remove $\geq 0.100$ ). 


\section{RESULTS}

First of all, the descriptive and correlation analyses are presented (tab. 2-3-4).

Table 2. Descriptive Statistics

\begin{tabular}{lrrrr}
\hline Variables & Mean & Std. Deviation & Skewness & Kurtosis \\
\hline EMP 2000-2009 & 64.77 & 6.80 & 0.002 & -0.537 \\
GERD 1995-2004 & 1.317 & 0.85 & 0.956 & 0.379 \\
SPENDING HR 1995-2004 & 5.30 & 1.13 & 0.717 & 0.606 \\
DEBT 1997-2006 & 48.68 & 23.26 & 0.489 & 0.617 \\
INTER 1: DEBT $\times$ SPENDING IN HR & 258.20 & 131.04 & 0.268 & -0.471 \\
INTER 2: DEBT $\times$ GERD & 68.24 & 53.80 & 0.749 & -0.317 \\
INTER 3: GERD $\times$ SPENDING IN HR & 7.47 & 6.07 & 1.425 & 1.639 \\
\hline
\end{tabular}

Table 3. Bivariate correlations

\begin{tabular}{clcccc}
\hline & & $\begin{array}{c}\text { EMP } \\
(2000-2009)\end{array}$ & $\begin{array}{c}\text { GERD } \\
(1995-2004)\end{array}$ & $\begin{array}{c}\text { SPENDING } \\
\text { HR (1995-2004) }\end{array}$ & $\begin{array}{c}\text { DEBT } \\
(1997-2006)\end{array}$ \\
\hline EMP & Pearson Correlation & 1 & $.590^{* *}$ & $.616^{* *}$ & -.103 \\
$(2000-2009)$ & Sig. (2-tailed) & & .000 & .000 & .125 \\
& N & & 225 & 225 & 225 \\
GERD & Pearson Correlation & 1 & $.509^{* * *}$ & $.209^{* * *}$ \\
$(1995-2004)$ & Sig. (2-tailed) & & .000 & .002 \\
& N & & 225 & 225 \\
SPENDING HR & Pearson Correlation & & & & .006 \\
$(1995-2004)$ & Sig. (2-tailed) & & & .933 \\
& N & & & 225 \\
DEBT & Pearson Correlation & & & \\
$(1997-2006)$ & & & & & 1 \\
\hline
\end{tabular}

** Correlation is significant at the 0.01 level (2-tailed) 
Table 4. Partial correlations

\begin{tabular}{lllccc}
\hline \multicolumn{2}{l}{ Control Variable } & & $\begin{array}{c}\text { EMP } \\
(2000-2009)\end{array}$ & $\begin{array}{c}\text { GERD } \\
(1995-2004)\end{array}$ & $\begin{array}{c}\text { SPENDING HR } \\
(1995-2004)\end{array}$ \\
\hline DEBT & EMP (2000-2009) & Correlation & 1 & .63 & .62 \\
$(1997-2006)$ & & Significance (2-tailed) & & .00 & .00 \\
& & df & 22 & 22 \\
& & GERD (1995-2004) & Correlation & 1 & .52 \\
& & Significance (2-tailed) & & .00 \\
& & df & & & 22 \\
& SPENDING HR & Correlation & & 1 \\
& & & & \\
\hline
\end{tabular}

Results of econometric modelling [1], without interaction terms, are in tables 5-8.

Table 5. Models ${ }^{a}$ and variables entered

\begin{tabular}{cll}
\hline Model & Variables Entered & \\
\hline 1 & SPENDING HR & Method \\
& 1995-2004 & Stepwise (Criteria: Probability-of-F-to-enter $\leq$ 0.050, Probability-of- \\
2 & GERD1995-2004 & F-to-remove $\geq 0.100)$. \\
3 & DEBT 1997-2006 & \\
\hline a) Dependent Variable: EMP 2000-2009 &
\end{tabular}

a) Dependent Variable: EMP 2000-2009 
Table 6. Coefficients of model ${ }^{a}$ [1]

\begin{tabular}{clcccc}
\hline \multirow{2}{*}{ Model } & & \multicolumn{2}{c}{ Unstandardized Coefficients } & & \\
\cline { 3 - 4 } & & $\mathrm{B}$ & Std. Error & $\mathrm{t}$ & Sig. \\
\hline \multirow{2}{*}{1} & (Constant) & 45.175 & 1.714 & 26.353 & .000 \\
& SPENDING HR 1995-2004 & 3.697 & .316 & 11.689 & .000 \\
2 & (Constant) & 47.280 & 1.601 & 29.535 & .000 \\
& SPENDING HR 1995-2004 & 2.559 & .336 & 7.609 & .000 \\
& GERD 1995-2004 & 2.979 & .448 & 6.643 & .000 \\
& (Constant) & 50.308 & 1.721 & 29.227 & .000 \\
& SPENDING HR1995-2004 & 2.401 & .328 & 7.328 & .000 \\
& GERD1995-2004 & 3.410 & .447 & 7.632 & .000 \\
& DEBT 1997-2006 & -0.057 & .014 & -4.029 & .000 \\
\hline
\end{tabular}

a. Dependent Variable: EMP 2000-2009

Table 7. Model Summary ${ }^{d}$ of model [1]

\begin{tabular}{ccccc}
\hline Model & R & R Square & $\begin{array}{c}\text { Adjusted R } \\
\text { Square }\end{array}$ & $\begin{array}{c}\text { Std. Error of the } \\
\text { Estimate }\end{array}$ \\
\hline 1 a. & $0.616^{\mathrm{a}}$ & 0.380 & 0.377 & 5.369 \\
2 b. & $0.695^{\mathrm{b}}$ & 0.483 & 0.478 & 4.915 \\
3 c. & $0.720^{\mathrm{c}}$ & 0.518 & 0.512 & 4.755 \\
\hline
\end{tabular}
a. Predictors: (Constant), SPENDING HR 1995-2004
b. Predictors: (Constant), SPENDING HR 1995-2004, GERD1995-2004
c. Predictors: (Constant), SPENDING HR 1995-2004, GERD1995-2004, DEBT1997-2006
d. Dependent Variable: EMP 2000-2009 
Table 8. ANOVAd of model [1]

\begin{tabular}{clrrrrr}
\hline \multirow{2}{*}{ Model } & & Sum of Squares & df & Mean Square & F & Sig. \\
\hline \multirow{2}{*}{$1 \mathrm{a}$ a. } & Regression & 3939.196 & 1 & 3939.196 & 136.640 & $0.000^{\mathrm{a}}$ \\
& Residual & 6428.887 & 223 & 28.829 & & \\
& Total & 10368.082 & 224 & & & \\
2 b. & Regression & 5005.305 & 2 & 2502.652 & 103.601 & $0.000^{\mathrm{b}}$ \\
& Residual & 5362.778 & 222 & 24.157 & & \\
& Total & 10368.082 & 224 & & & \\
$3 \mathrm{c}$. & Regression & 5372.276 & 3 & 1790.759 & 79.218 & $0.000^{\mathrm{c}}$ \\
& Residual & 4995.806 & 221 & 22.605 & & \\
& Total & 10368.082 & 224 & & & \\
\hline
\end{tabular}

a. Predictors: (Constant), SPENDING HR 1995-2004

b. Predictors: (Constant), SPENDING HR 1995-2004, GERD 1995-2004

c. Predictors: (Constant), SPENDING HR 1995-2004, GERD 1995-2004, DEBT 1997-2006

d. Dependent Variable: EMP 2000-2009

Econometric modelling [2], with interaction terms, considers as predictors: GERD 1995-2004; SPENDING HR 1995-2004; DEBT 1997-2006; INTER 1 DEBT-GERD, INTER 2 DEBTSPENDING HR, INTER 3 GERD-SPENDING HR. The Stepwise method (Criteria: Probability-of-Fto-enter $\leq 0.050$, Probability-of-F-to-remove $\geq 0.100$ ) considers the variables of table 9 .

Table 9. Models and variables entered

\begin{tabular}{cl}
\hline Model & Variables Entered $^{\text {a) }}$ \\
\hline 1 & INTER GERD-SPENDING \\
2 & + SPENDING HR 1995-2004 \\
3 & + GERD 1995-2004 \\
4 & + INTER DEBT-GERD \\
\hline
\end{tabular}

Note: a) Dependent Variable: EMP 2000-2009;

Method Stepwise (Criteria: Probability-of-F-to

-enter $\leq 0.050$, Probability-of-F-to-remove $\geq 0.100$ ). 
The coefficients of estimated relationship [2] are in table 10, adjusted $\mathrm{R}^{2}$ and its standard error of the estimate are in table 11, ANOVA is in table 12. Appendix shows the standardized residual plots (Histogram in Figure 1A, Normal probability plot in Figure 2A).

Table 10. Coefficients of model ${ }^{a}[2]$

\begin{tabular}{|c|c|c|c|c|c|c|}
\hline \multirow[t]{2}{*}{ Model } & & \multicolumn{2}{|c|}{$\begin{array}{l}\text { Unstandardized } \\
\text { Coefficients }\end{array}$} & \multirow{2}{*}{$\begin{array}{c}\text { Standardized } \\
\text { Coefficients }\end{array}$} & \multirow[b]{2}{*}{$\mathrm{t}$} & \multirow[b]{2}{*}{ Sig. } \\
\hline & & $\mathrm{B}$ & Std. Error & & & \\
\hline \multirow[t]{2}{*}{1} & (Constant) & 59.526 & .563 & & 105.821 & .000 \\
\hline & INTER GERD-SPENDING & .702 & .058 & .627 & 12.004 & .000 \\
\hline \multirow[t]{3}{*}{2} & (Constant) & 50.384 & 1.855 & & 27.156 & .000 \\
\hline & INTER GERD-SPENDING & .430 & .077 & .384 & 5.622 & .000 \\
\hline & SPENDING HR 1995-2004 & 2.108 & .410 & .351 & 5.144 & .000 \\
\hline \multirow[t]{4}{*}{3} & (Constant) & 37.925 & 3.118 & & 12.161 & .000 \\
\hline & INTER GERD-SPENDING & -1.174 & .339 & -1.048 & -3.466 & .001 \\
\hline & SPENDING HR 1995-2004 & 4.268 & .592 & .712 & 7.206 & .000 \\
\hline & GERD 1995-2004 & 9.865 & 2.034 & 1.234 & 4.850 & .000 \\
\hline \multirow[t]{5}{*}{4} & (Constant) & 36.280 & 2.953 & & 12.288 & .000 \\
\hline & INTER GERD-SPENDING & -1.445 & .323 & -1.290 & -4.474 & .000 \\
\hline & SPENDING HR 1995-2004 & 4.475 & .559 & .746 & 8.003 & .000 \\
\hline & GERD 1995-2004 & 15.153 & 2.151 & 1.895 & 7.044 & .000 \\
\hline & INTER DEBT-GERD & -.064 & .012 & -.509 & -5.403 & .000 \\
\hline
\end{tabular}

a. Dependent Variable: EMP 2000-2009

It is also important to consider the following result:

$$
\text { Marginal effect: } \frac{\partial E M P}{\partial G E R D}=15.153-1.445 \text { SPENDING }-0.064 D E B T
$$

If we consider the average value of variables:

SPENDING=5.30

$\mathrm{DEBT}=48.68$

the marginal effect is 4.37 . This can be also calculated per countries and represented by a graph. 
Table 11. Model Summary ${ }^{e}$ of model [2]

\begin{tabular}{ccccc}
\hline Model & R & R Square & $\begin{array}{c}\text { Adjusted R } \\
\text { Square }\end{array}$ & $\begin{array}{c}\text { Std. Error of } \\
\text { the Estimate }\end{array}$ \\
\hline 1 a. & $.627^{\mathrm{a}}$ & .393 & .390 & 5.3145 \\
$2 \mathrm{~b}$. & $.676^{\mathrm{b}}$ & .457 & .452 & 5.0348 \\
$3 \mathrm{c}$. & $.714^{\mathrm{c}}$ & .509 & .503 & 4.7974 \\
$4 \mathrm{~d}$. & $.753^{\mathrm{d}}$ & .567 & .559 & 4.5179 \\
\hline
\end{tabular}

a. Predictors: (Constant), INTER GERD-SPENDING

b. Predictors: (Constant), INTER GERD-SPENDING, SPENDING HR 1995-2004

c. Predictors: (Constant), INTER GERD-SPENDING, SPENDING HR 19952004, GERD 1995-2004

d. Predictors: (Constant), INTER GERD-SPENDING, SPENDING HR 19952004, GERD 1995-2004, INTER DEBT-GERD

e. Dependent Variable: EMP 2000-2009

Table 12. ANOVA of model [2]

\begin{tabular}{ccccccc}
\hline \multirow{2}{*}{ Model } & & $\begin{array}{c}\text { Sum of } \\
\text { Squares }\end{array}$ & df & $\begin{array}{c}\text { Mean } \\
\text { Square }\end{array}$ & F & Sig. \\
\hline \multirow{2}{*}{1} & Regression & 4069.656 & 1 & 4069.656 & 144.089 & $.000^{\mathrm{a}}$ \\
& Residual & 6298.427 & 223 & 28.244 & & \\
& Total & 10368.082 & 224 & & & \\
2 & Regression & 4740.515 & 2 & 2370.258 & 93.503 & $.000^{\mathrm{b}}$ \\
& Residual & 5627.567 & 222 & 25.349 & & \\
& Total & 10368.082 & 224 & & & \\
& Regression & 5281.808 & 3 & 1760.603 & 76.499 & $.000^{\mathrm{c}}$ \\
& Residual & 5086.274 & 221 & 23.015 & & \\
& Total & 10368.082 & 224 & & & \\
& Regression & 5877.617 & 4 & 1469.404 & 71.990 & $.000^{\mathrm{d}}$ \\
& Residual & 4490.465 & 220 & 20.411 & & \\
& Total & 10368.082 & 224 & & & \\
\hline
\end{tabular}

a. Predictors: (Constant), INTER GERD-SPENDING

b. Predictors: (Constant), INTER GERD-SPENDING, SPENDING HR 1995-2004

c. Predictors: (Constant), INTER GERD-SPENDING, SPENDING HR 1995-2004, GERD 1995-2004

d. Predictors: (Constant), INTER GERD-SPENDING, SPENDING HR 1995-2004, GERD 1995-2004, INTER DEBT-GERD

e. Dependent Variable: EMP 2000-2009 
Table 13 shows the estimated relationships for three different periods. Results confirm the negative effect of public debt on employment rate and the fruitful impact of spending on R\&D and on human resources on employment growth. Parameters show a consistency over time.

Table 13: Parametric estimates of the Employment rate on R\&D Intensity, Spending HR, Public Debt

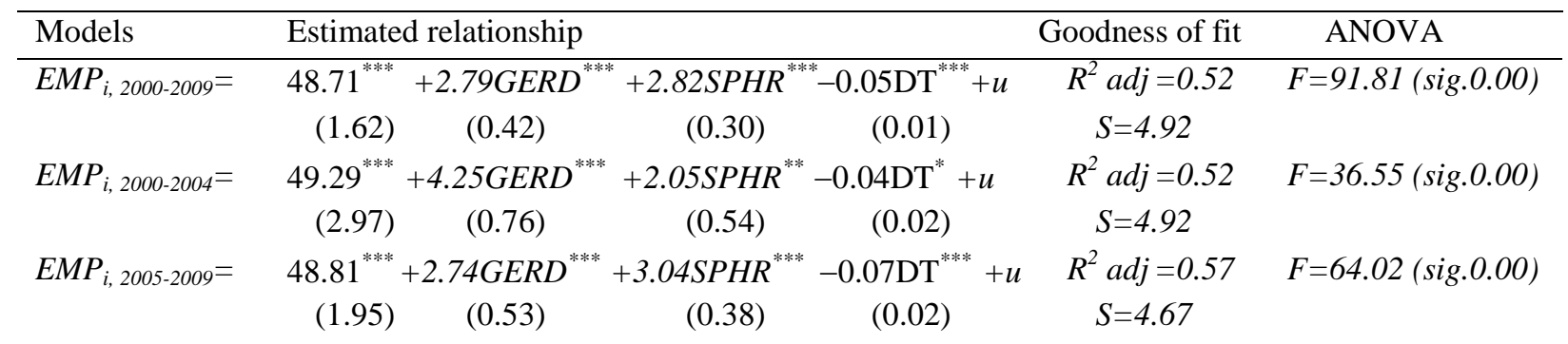

Note: The dependent variable is Employment rate \%; The independent variables are: GERD=Gross domestic expenditure on $\mathrm{R} \& \mathrm{D}(\%$ of GDP) at $-\Delta t$; SPHR= Spending on Human Resources-Total public expenditure on education as a $\%$ of GDP at $-\Delta t$; $\mathrm{DT}=$ General government consolidated gross debt as a $\%$ of GDP at $-\Delta t$. Estimates of the constant and $\beta_{\mathrm{i}}$ have underneath them, in parentheses, standard error. Adjusted $\mathrm{R}^{2}$ of the regression has below it, the standard error of the regression. Fisher test has to its right the significance. $* * * \quad$ Parameter is Significant at 0.001; * Parameter is Significant at 0.1.

\section{DISCUSSION AND POLITICAL ECONOMY IMPLICATIONS}

Europe since 1990s has been experiencing a "secular rise of unemployment" (Addison and Teixteira, 2001, p. 191). This European unemployment, recently, has been intensifying the effects due to economic downturn of 2007 2010 and succeeding crisis of sovereign debt of countries that has generating turmoil within the Eurozone. As Europe has to design an apt political economy to support new pattern of employment growth, this paper investigates the relationship between employment and technological variables, considering the interaction with the structural indicator of public debt that affects, more and more, government policies of European countries. First of all, the study here shows a high positive association among employment, GERD and Spending in Human Resources, significant at the 0.01 level (table 3). In addition, if the relationship between Employment, GERD and spending on human resources is analyzed by partial correlation, controlling -ceteris paribus- the public debt of countries (tab. 4), coefficients of partial correlation are higher:

$$
\begin{aligned}
& r_{\text {Employment, GERD } \mid \text { Debt }}=62.8 \% \\
& r_{\text {Employment, Spending in } H R \mid \text { Debt }}=62.0 \%
\end{aligned}
$$

respectively (sign.0.00).

The paper also analyzes the interaction of technological variables on employment rate by multiple regression models. The first thing to be said about these estimated relationships [1] and [2] is that the significance of coefficients of the equations is high and the explanatory power of the equation is good. In fact, table 7 shows that final model [1] explains more than $51 \%$ variance in the data, whereas final model [2] explains about $57 \%$ (see adj. $\mathrm{R}^{2}$ in table 11 ). ANOVA shows for both models the significance of $F$-test (table 8 and 12). In particular, the estimated relationship (model 3 in table 6, without interaction among variables) shows an expected employment rate increase of approximately $2.4 \%$ for a spending on human resources increase of $1 \%$ (ceteris paribus GERD and public debt) and an expected employment rate increase of approximately $3.4 \%$ for a GERD increase of $1 \%$ 
(ceteris paribus spending in human resources and public debt), whereas the moderate negative impact of public debt is showed by the third coefficient: an expected employment rate reduction of approximately 0.06 for a public debt increase of $1 \%$ (ceteris paribus spending in human resources and GERD). The final model 4 in table 10, with interaction of variables, finds some highly significant variables through stepwise method based on probability-of- $F$-toenter $\leq 0.05$, Probability-of-F-to-remove $\geq 0.1$. This model shows the higher impact of R\&D intensity and spending in human resources on employment rate of countries, as well as it shows the negative interaction between GERD and spending on human resources, public debt and R\&D intensity (GERD). In short, these models [1] and [2] show the fruitful impact of gross domestic expenditure on $R \& D$ as percentage of GDP and total expenditure on education (as percentage of GDP) on employment rate of European countries. This statistical analysis provides main results to social planner, mainly of advanced countries, to design policies of employment increase, considering technological drivers in presence of sovereign debt implications.

Modern economic literature attempts to explain the determinants of growth considering $R \& D$ and knowledge creation that have main effects on technological change with positive spillover for employment and productivity gains of countries (cf. Romer, 1990). In fact, high growth and employment in US and Europe are driven by investments in machinery and equipment, but also by intangible assets, represented by Research and Development (R\&D) and human capital investment. R\&D leads to technological innovations that skilled human capital can absorb to spur economic growth of economies ( $c f$. Corley et al., 2002, p. 266ff).

The study here also shows the negative impact of general government consolidated gross debt (as percentage of GDP) on employment rate as well as on technological indicators (GERD and spending on human resources by interaction effects). In fact, Sargent (2012) argues the risk of high sovereign debt for some Europe countries, driven by government policies, which contributes to maintain persistently high European unemployment.
In order to spur employment, it is important to increase $R \& D$ intensity and spending in human resource, but these research policies are affected by austerity packages in presence of high consolidated gross debt and negative budget deficit by countries, e.g. in Greece, Spain, Italy, etc. In fact, Bajo-Rubio et al. (2010) re-examine the long-run sustainability of budget deficits in Spain, and show that fiscal authorities would cut deficits only if they are large, which would assure in turn their long-run sustainability (p. 263).

Economic growth is the engine of employment rate increase, and innovation is a main determinant of employment and economic growth. A vital trade-off that policy makers have to deal with, in period of economic turmoil, is: either to support R\&D spending in order to spur employment and economic growth or to apply balanced-budget rules to reduce public debt that, as consequence, decrease government spending, included R\&D intensity, with effects that might be negative for patterns of economic growth.

First of all, it is important to note that government policy has to be applied considering the phase of business cycle. If it is considered European orientation, a social planner should apply a balanced budget rule and public debt reduction to improve the stability of the economic system and spur economic growth and employment. Economic literature shows that whether the government strictly applies a balanced-budget rule to reduce public deficit and public debt, the amplitude of business cycle increases by fostering aggregate demand during booms via tax cuts and higher public expenditures and by lowering demand during recessions through a fiscal contraction (SchmittGrohé, 1995, p. 976 and 977, passim). In particular, balanced-budget rule can be a source of economic instability and this result is confirmed in presence of (high) public debt that should remain constant over time. Several models do not suggest for governments a balancedbudget rule on average, since it affects (narrows) the political economy of driving surplus and deficits, by borrowing and lending, to smooth taxes; thereby a balanced-budget rule is not an optimal policy. In addition, "the welfare consequences of decreasing ratio of debt/output at the exogenous growth rate are negligible" (Stockman, 2001, p. 439). Maastricht treatise in 
1992 has established fiscal rules to restrict the ratio of the annual government deficit to gross domestic product (GDP) at $\max 3 \%{ }^{4}$ and the ratio of gross government debt to GDP that must not exceed $60 \%$. This is considered a sub-optimal policy (cf. Stockman, 2001) such that several European countries, with current fluctuations of business cycles, have not improved the patters of employment and economic growth ${ }^{5}$. A balancedbudget rule, with a (high) public debt, inhibits the possibility by government to smooth taxes, and according to reputation model by Stockman (2004, p. 382, p. 383 and 384) predicts default (i.e. incapacity of governments to honor its debt obligations), although other main mechanisms works as incentive to have a reputation as a reliable borrowed. Stockman (2010) also shows the possibility of chaotic equilibria under a balanced-budget rule and a critical role is played by endogenous labor tax.

In short, the study here confirms the driving role of innovation on employment growth, but innovation as engine of growth is affected in negative way by public debt that has also a low negative impact on employment rate. As innovation has a high positive effect on employment, whereas public debt has a negligible impact on employment, a government policy could support innovation by public debt, ceteris paribus other structural indicators, and indirectly employment growth. Public debt of European countries, after the economic downturn of 2008-2010, has sharply increased trajectory, since governments have supported the financial system, and applied fiscal stimulus and dropped in tax revenue (Corsetti et al., 2010). Tabellini and Alesina (1990, p. 37ff) argue that most governments choose, a priori, a non-optimal debt policy by budget deficits, because of disagreement between current and future

4 European summit held at Brussels in December 2011 has suggested to reduce this value at $0.5 \%$, except in periods of recessions.

${ }^{5}$ Pros of this fiscal rule are the reduction of government spending, cons are the inhibition of stabilization fiscal policy that can increase the fluctuations of business cycle. Stockman (2001, p. 440) argues: "in Europe, ...without strict fiscal guidelines, there will be excessive deficits (perhaps politically motivated) that are not consistent with long-term solvency". In fact, nowadays in several European countries there is the problem of sovereign debt such as in Greece, Italy, etc. majorities such as in Italy ("time inconsistency in the dynamic social choice problem that determines the size of budget deficits", p. 37). Public debt is a complex economic issue (Barro, 1979) and government should limit government spending ${ }^{6}$ but political pressures by European institutions to reduce public debt in the short-run should be assessed with accuracy and awareness since can generate more negative socio-economic effects than benefits for employment and economic growth. Although it is a desirable target, reduction of sovereign debt of some European countries is not an easy task and should be pursued by long-run government policies, considering the fluctuations of business cycle, to support steady-state patterns of economic growth. In particular, the Europe has focused on downsizing of the ratio of public debt to GDP and of the fiscal deficit as percentage of GDP as well as on balanced-budget rules for members. If these targets have to be achieved in the short run, at any price with austerity packages, under political pressure of European Institutions and recurrent shocks of business cycles, can generate negative effects for long-run patterns of employment and economic growth, shaking stability of countries to its foundations. Antonucci and Pianta (2002, p. 306) also claim that: "macroeconomic constraints of Economic and Monetary Union in Europe have put a serious limit on the economic dynamics of national economies, and of manufacturing industries in particular". Modern economic research shows that some of these rules are not optimal policy considering the initial level of the public debt and can generate aggregate instability (Schmitt-Grohé and Uribe, 1997; Stockman, 2010). According to Stockman (2004, p. 383): "The ability to borrow is desirable because debt serves as a buffer to help smooth distortionary taxes over time resulting in higher economic welfare". As a matter of fact, fiscal guidelines of the Monetary European Union, since Maastrict treatise, have deteriorated the economic dynamics and structure of countries in presence of the global financial crisis over 2007-2010 and economic turmoil over

\footnotetext{
${ }^{6}$ Corsetti et al. (2010, p. 45) argue: "consolidation efforts are likely to include not only tax increases but also sizeable spending cuts. . . . analysis suggests that such prospective spending cuts generally enhance the expansionary effect of current fiscal stimulus" (original emphasis).
} 
2011-2012. European policy makers should have the awareness that to support employment and economic growth by Lisbon strategy (i.e. increasing R\&D intensity of countries, $c f$. Room, 2005), the strict fiscal rules, public debt downsizing, balanced-budget rules stressed in the short run for different economic structures of European countries can reduce the common patterns of economic growth and trigger European instability and economic shocks in the interlinked relationships among countries.

In order to spur employment growth by innovation into the European countries, it is important to design effective and efficient lungrun political economy, considering the respective structural indicators and specificity of economic structure, to allow the economic system to dry out slowly public debt without inserting damping factors for patterns of economic and employment growth. Although other socio-demographiceconomic factors are important for a systematic analysis of this critical relationship, models discussed here, focusing on key critical variables, provide interesting results to understand basic vital interactions that support, or are processes of friction for pattern of technological innovation and employment growth. This study, of course, is a starting point for further investigations based on more complex and comprehensive models. 


\section{REFERENCES}

Acemoglu D. (2002) "Technical change, inequality, and the labour market", Journal of Economic Literature, vol. 40, n. 1, pp. 7-72.

Addison J. T., Teixeira P. (2001) "Technology, Employment and Wages", Labour, vol. 15, n. 2, pp. 191-219.

Aghion P., Howitt P. (1992) "A Model of Growth Through Creative Destruction", Econometrica, vol. 60, n. 2, pp. 323-351.

Amaral P., Jacobson M. (2011) "Why some European countries and not U.S.?", Economic Trend, Federal Reserve Bank of Cleveland, USA (http://www.clevelandfed.org/, accessed on December 2011)

Antonucci T., Pianta M. (2002) "Employment Effects of Product and Process Innovation in Europe", International Review of Applied Economics, vol. 16, n. 3, pp. 295-307.

Bajo-Rubio O., Díaz-Roldán C., Esteve V. (2010) "On the sustainability of government deficits: some long-term evidence for Spain, 1850-2000", Journal of Applied Economics, vol. 13 , n. 2 , pp. $263-281$.

Barro R. J. (1979) "On the determination of the public debt", Journal of Political Economy, vol. 87, n. 5, pp. 940-971.

Bogliacino F., Pianta M. (2010), "Innovation and Employment: a Reinvestigation using Revised Pavitt classes", Research Policy, vol. 39, n. 6, pp.799-809.

Caballé J., Santos M. S. (1993) "On Endogenous Growth with Physical and Human Capital", Journal of Political Economy, vol. 101, n.6, pp. 1042-1067.

Corley M., Michie J., Oughton C. (2002) "Technology, Growth and Employment", International Review of Applied Economics, vol. 16, n. 3, pp. 265-276.

Corsetti G., Kuester K., Meier A., Müller G. (2010), "Debt Consolidation and Fiscal Stabilization of Deep Recessions", The American Economic Review, vol. 100, n. 2, pp. 41-45.
David P., Hall B., Toole, A. (2000) "Is public R\&D a complement or a substitute for private R\&D? A review of the economic evidence", Research Policy, vol. 29, n. 4-5, pp.497-529.

Eurostat (2012) http://epp.eurostat.ec.europa. eu/portal/page/portal/statistics/themes (accessed on January 2012)

Funke M., Strulik H. (2000) "On endogenous growth with physical capital, human capital and product variety", European Economic Review, vol. 44, n. 3, pp. 491-515.

Goel R. K., Payne J. E., Ram R. (2008), “R\&D expenditures and U.S. economic growth: A disaggregated approach", Journal of Policy Modeling, vol. 30, n. 2, pp. 237-250.

Grossman G., Helpman E. (1991), Innovation and Growth in the Global Economy, MIT Press: Cambridge.

Grossmann V. (2007), "How to promote R\&Dbased growth? Public education expenditure on scientists and engineers versus $R \& D$ subsidies", Journal of Macroeconomics, vol. 29, n.4, pp. 891-911.

Lucas R. E. Jr. (1988) "On the Mechanics of Economic Development", Journal of Monetary Economics, vol. 22, n. 1, pp. 3-42.

Lundvall B-A. (1992), National systems of innovation, Pinter Publishers, London.

Mastrostefano V., Pianta M. (2009) “Technology and jobs", Economics of Innovation and New Technology, vol. 18, n. 8, pp. 729-741.

Michie J., Oughton C., Pianta M. (2002) "Innovation and the Economy", International Review of Applied Economics, vol. 16, n. 3, pp. 253-264.

Ogawa K. (2007) "Debt, R\&D Investment and Technological Progress: A Panel Study of Japanese Manufacturing Firms' Behavior during the 1990s", Journal of Japanese and International Economies, vol. 21, n. 4, pp. 403423.

Pini P. (1995) "Economic growth, technological change and employment: empirical evidence for a cumulative growth model with external causation for nine OECD countries", Structural Change and Economic Dynamics, vol. 6, n. 2, pp. 185-213. 
Romer P. M. (1990) "Endogenous Technological Change", Journal of Political Economy, vol. 98, n. 5, pp. S71-102.

Room G. (2005) The European Challenge: Innovation, Policy Learning and Social Cohesion in the New Knowledge Economy, The Policy Press, Bristol.

Sapir A., Aghion P., Bertola G., Hellwig M., Pisani-Ferry J., Rosati D.,Vinals J., Wallace H. (2004) "An Agenda for a Growing Europe: The Sapir Report", OUP Catalogue, Oxford University Press, number 9780199271498, March.

Sargent T. J. (2012) “Chicago Booth's 2011 management conference", May 20, at The Gary Becker Milton Friedman Institute for Research in Economics (http://mfi.uchicago.edu/events/ 20110520_sovrisk/ accessed at 5 January 2012)

Schmitt-Grohé S., Uribe M. (1997) "Balancedbudget rules, distortionary taxes and aggregate instability", Journal of political economy, vol. 105 , n. 5 , pp. 976-1000.

Stockman D. R. (2001) "Balanced-Budget Rules: Welfare Loss and Optimal Policies", Review of Economic Dynamics, vol. 4, n. 2, pp. 438-459.

Stockman D. R. (2004) "Default, Reputation and Balanced-Budget Rules", Review of Economic Dynamics, vol. 7, n. 2, pp. 382-405.

Stockman D. R. (2010) "Balanced-Budget Rules: Chaos and Deterministic Sunspots", Journal of Economic Theory, vol. 145, n. 3, pp. 10601085.

Strulik H. (2005) "The role of human capital and population growth in R\&D-based models of economic growth", Review of international economics, vol. 13, n. 1, pp. 129-145.

Tabellini G., Alesina A. (1990) "Voting on the budget deficit", The American Economic Review, vol. 80, n. 1, pp. 37-49. 


\section{APPENDIX}

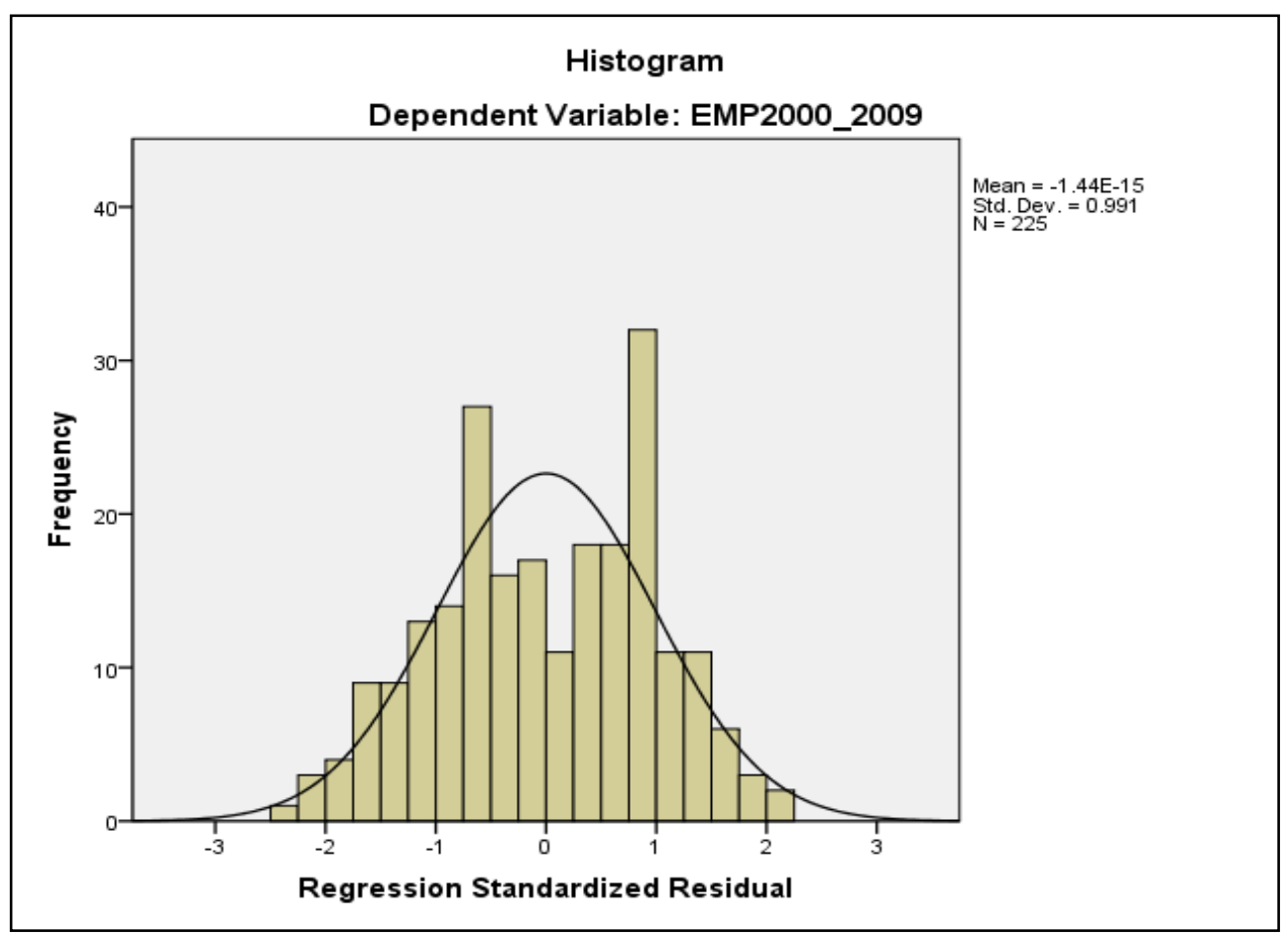

Figure 1A: Z residuals Histogram

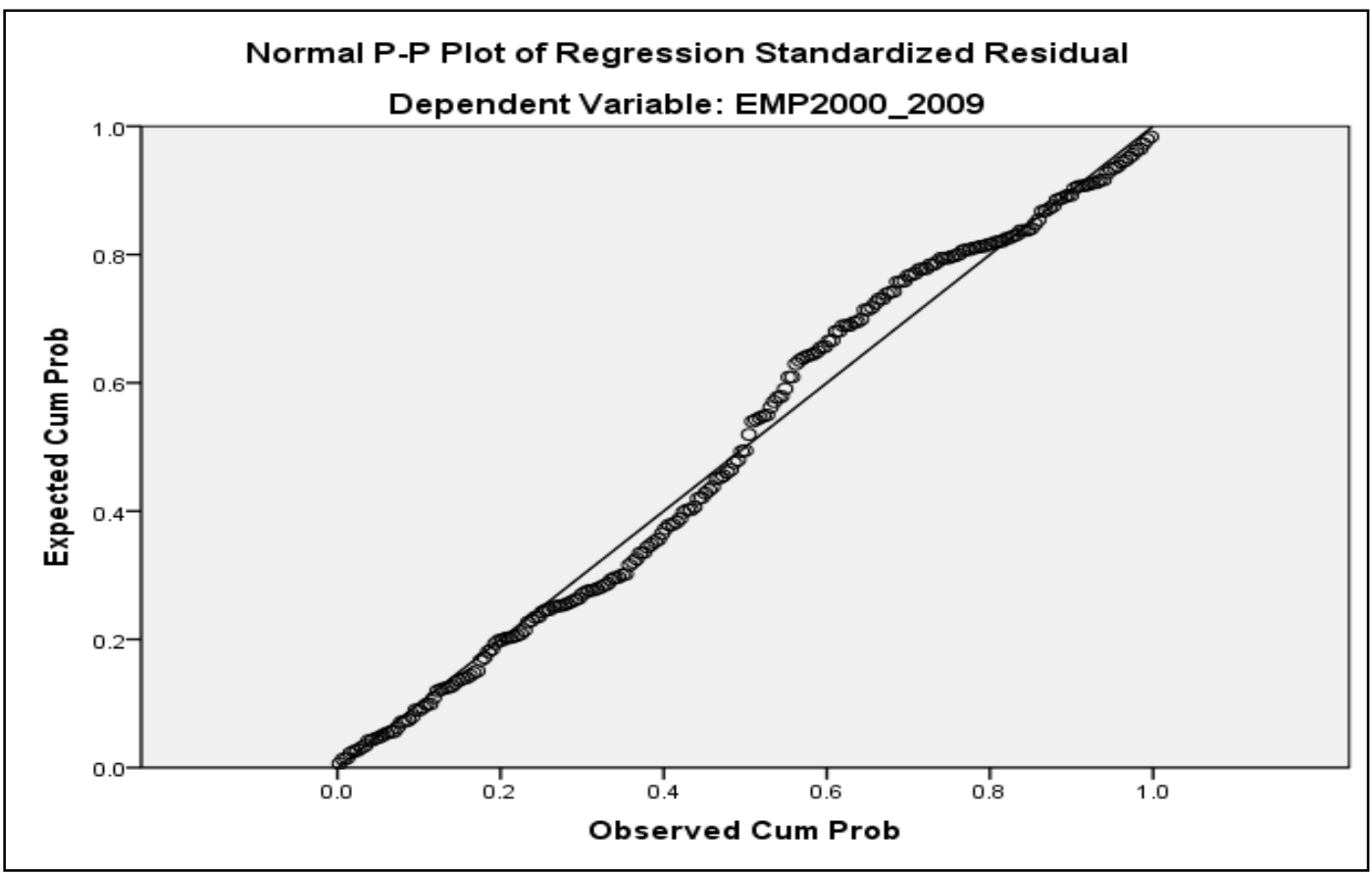

Figure 2A: Z residuals Normal P-P Plot 


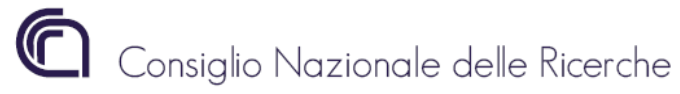

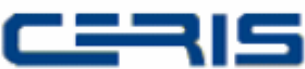 \\ Working Paper Cnr-Ceris}

ISSN (print): 1591-0709ＩSSN (on line): 2036-8216

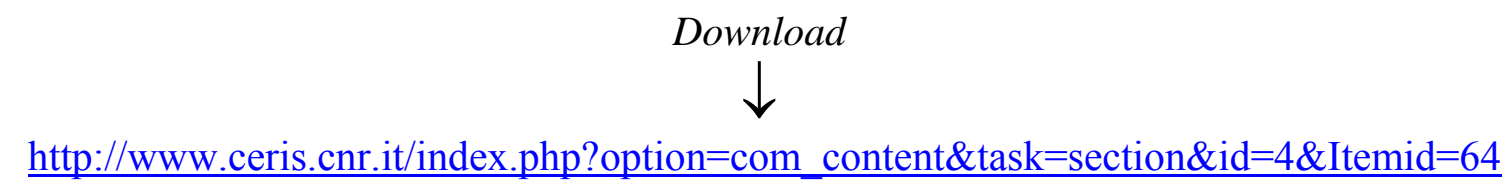

Hard copies are available on request,

please, write to:

Cnr-Ceris

Via Real Collegio, n. 30

10024 Moncalieri (Torino), Italy

Tel. +390116824.911 Fax +390116824.966

segreteria@ceris.cnr.it http://www.ceris.cnr.it

\section{Copyright (C) 2012 by Cnr-Ceris}

All rights reserved.

Parts of this paper may be reproduced with the permission of the author(s) and quoting the source. 